Communication

\title{
Selective Photocatalytic Oxidation of 5-HMF in Water over Electrochemically Synthesized $\mathrm{TiO}_{2}$ Nanoparticles
}

\author{
Anna Ulyankina ${ }^{1, *}$, Sergey Mitchenko ${ }^{2}$ and Nina Smirnova ${ }^{1}$ \\ 1 Platov South-Russian State Polytechnic University (NPI), 346428 Novocherkassk, Russia; \\ smirnova_nv@mail.com \\ 2 Institute of Physical-Organic Chemistry and Coal Chemistry, 83114 Donetsk, Ukraine; samit_rpt@mail.ru \\ * Correspondence: anya-barbashova@yandex.ru
}

Received: 2 May 2020; Accepted: 28 May 2020; Published: 29 May 2020

\begin{abstract}
TiO}_{2}$ nanoparticles were prepared via an electrochemical method using pulse alternating current and applied in the photocatalytic oxidation of 5-hydroxymethylfurfural (HMF) to 2,5-diformylfuran (DFF). Its physicochemical properties were characterized by SEM, HRTEM, XRD, and BET methods. The effect of scavenger and UVA light intensity was studied. The results revealed that electrochemically synthesized $\mathrm{TiO}_{2}$ nanoparticles exhibit higher DFF selectivity in the presence of methanol (up to $33 \%$ ) compared with commercial samples.
\end{abstract}

Keywords: 5-hydroxymethylfurfural; 2,5-diformylfuran; $\mathrm{TiO}_{2}$; electrochemical synthesis; pulse alternating current

\section{Introduction}

5-hydroxymethylfurfural (HMF) is one of the most versatile "biomass platform molecules" produced from abundant and renewable lignocellulose-derived glucose. HMF can be further converted into a series of high-value chemicals such as 2,5-diformylfuran (DFF), 5-hydroxymethyl-2-furancarboxylic acid (HMFCA), and 2,5-furandicarboxylic acid (FDCA) [1]. Among them, DFF is regarded as a valuable starting material for the polymer, pharmaceutical, and other industries [2]. The catalytic (both homogeneous and heterogeneous) oxidation of HMF is the most promising and extensively studied method to produce DFF. However, these catalytic processes are often carried out in organic solvents and at elevated temperatures and pressures, which makes them energy intensive and harmful to the environment $[3,4]$. Heterogeneous photocatalysis has become an attractive technology for air and wastewater treatment due to the easy in situ formation of powerful oxidizing agents in the presence of photocatalysts under mild conditions (ambient temperature and pressure, solar radiation, etc.). [5,6]. Recently, a lot of efforts have been made in the field of selective and partial photocatalytic oxidation or reduction of diverse substrates to form compounds of higher value in aqueous solutions (organic synthesis) $[7,8]$. However, to control the selectivity of HMF oxidation to DFF in an aqueous medium is challenging. It is reported that a number of factors, such as the type of photocatalyst and crystallinity, as well as the type of irradiation, can affect the photocatalytic oxidation of HMF to synthesize DFF $[9,10]$. A lot of research is devoted to the application of new promising photoactive materials [11]. However, $\mathrm{TiO}_{2}$-based photocatalysts are more attractive for use in photocatalytic technology due to their stability (both chemical and physical) and nontoxicity [12,13]. It is well documented in the literature that physicochemical properties, such as phase and surface structure, light-absorbing ability, and morphology, vary greatly depending on the synthesis method, and even a small change in the preparation procedure can lead to a large difference in photocatalytic activity [13]. Electrochemical methods are a green and beneficial alternative 
to traditional synthetic methods. They are easy to scale and very attractive for industrial applications. In our previous studies, the pulse alternating current (PAC) synthesis was described as a promising strategy producing highly active nanosized materials based on transition metal oxides, including $\mathrm{SnO}_{2}-\mathrm{SnO}$ nanocomposite [14], $\mathrm{ZnO}$ [15], $\mathrm{Co}_{3} \mathrm{O}_{4} / \mathrm{CoOOH}$ [16], and $\mathrm{CuO}_{\mathrm{x}}$ [17] for various applications.

In the present study, $\mathrm{TiO}_{2}$ nanoparticles $\left(\mathrm{TiO}_{2}-\mathrm{NPs}\right)$, which have been prepared electrochemically under pulsed alternating current conditions, were used in the oxidation of HMF as a photocatalyst.

\section{Materials and Methods}

\subsection{Photocatalyst Preparation}

$\mathrm{TiO}_{2}$-NPs were synthesized by an electrochemical process using pulse alternating current (PAC) followed by thermal treatment. An aqueous electrolyte solution was prepared by dissolving a $\mathrm{NaCl}$ salt in distilled water at a concentration of $2 \mathrm{M}$. An electrochemical cell equipped with a cooling jacket was filled with the electrolyte solution. The Ti plates $(99.7 \%)$ used as electrodes were immersed into the cell parallel to each other at a distance of $1 \mathrm{~cm}$ between them. The asymmetric PAC was then adjusted using a self-made source. The anodic:cathodic average current density ratio $\left(\mathrm{j}_{\mathrm{a}}: \mathrm{j}_{\mathrm{k}}\right)$ was $1.0: 0.2 \mathrm{~A} / \mathrm{cm}^{2}$. The current waveform used in the study is illustrated in Figure 1.

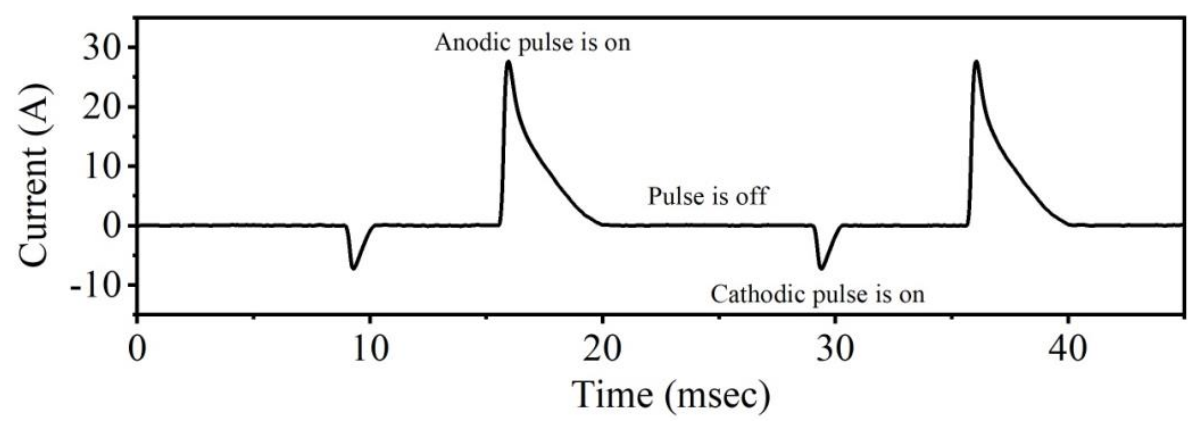

Figure 1. The current waveform during pulse alternating current (PAC) synthesis.

A magnetic stirrer inside the cell maintained the mixing speed in the solution at $400 \mathrm{rpm}$. A reaction time of 20 min was selected to prevent a considerable deterioration of the Ti electrode. After synthesis, the product was separated by filtration and washed with distilled water. The collected sample was dried in an oven at $80^{\circ} \mathrm{C}$, and then calcined at $500^{\circ} \mathrm{C}$ in air for $3 \mathrm{~h}$.

\subsection{Characterization}

The crystalline phase was analyzed by X-ray diffraction (XRD) on an ARL X'TRA diffractometer using $\mathrm{Cu} \mathrm{K} \alpha$ radiation $(\lambda=1.5406 \AA)$ in $0.02^{\circ}$ increments. The size of nanoparticles was calculated using the Scherrer equation:

$$
\mathrm{d}_{\mathrm{XRD}}=\frac{K \lambda}{\beta \cos \theta}
$$

where $\mathrm{d}_{\mathrm{XRD}}$ is crystallite size (nm), $\lambda, \theta$, and $\beta$ are X-ray wavelength, Bragg diffraction angle, and full width at half-maximum (FWHM) of the diffraction peak, respectively.

Morphological characteristics were observed using a scanning electron microscope (SEM) Tescan Vega $3 \mathrm{SB}$ with Oxford Instruments X-Act EDS detector. Fine structural analysis was performed on a JEOL JEM-2100 transmission electron microscope (TEM). The main lattice spacing of the crystallite structure was calculated by means of a fast Fourier transform analysis of high-resolution TEM images. Specific surface area analysis via the Brunauer-Emmett-Teller (BET) method was done on a Quantachrome NOVA 1200e instrument at 77.3 K. 


\subsection{Photocatalytic Procedure}

Photocatalytic reactions were carried out in a quartz beaker $(100 \mathrm{~mL})$ under ambient conditions. The suspension was irradiated with a spotlight source (Hamamatsu, LC8) at a wavelength of $365 \mathrm{~nm}$. The suspension in the beaker was irradiated from the top; the radiation energy ranged from 3.0 to $6.0 \mathrm{~mW} \mathrm{~cm}^{-2}$, which was measured using a UV34 Lux Meter (PCE). The initial concentration of the used substrate and photocatalyst was $0.4 \mathrm{mM}$ and $1.0 \mathrm{~g} \mathrm{~L}^{-1}$, respectively. The experiments were carried out under aerobic conditions with continuous bubbling of $\mathrm{O}_{2}$ at a flow rate of $3 \mathrm{~mL} / \mathrm{min}$. A run was also carried out with the addition of methanol and $\mathrm{Na}_{2} \mathrm{CO}_{3}$ as the scavenger for hole and $\mathrm{OH} \bullet$, respectively. Before turning on the lamp, the suspension was kept in an ultrasonic bath for $5 \mathrm{~min}$, and then stirred for $30 \mathrm{~min}$ to achieve adsorption-desorption equilibrium. The amount of HMF adsorbed by the catalyst in the dark was fairly low, i.e., less than $2 \%$ of the initial HMF amount. During the run, the aliquots of the aqueous suspension were taken at fixed time intervals and centrifuged $(15,000 \mathrm{rpm})$ before analysis.

The reaction solution was analyzed by high-performance liquid chromatography (HPLC) instrument (Agilent 1260 LC, stable bond C18 column). The mobile phase solution, consisting of $70 \%$ acetonitrile and $30 \%$ ultrapure water, was supplied to the column at $30{ }^{\circ} \mathrm{C}$ and a flow rate of $0.5 \mathrm{~mL} \mathrm{~min}{ }^{-1}$. The amounts of HMF and DFF were determined from a calibration curve obtained using standard solutions of these compounds. The following formula was used to calculate the selectivity to DFF:

$$
\text { Select. }(\%)=\frac{M_{t, D F F}}{M_{o, H M F}-M_{t, H M F}} \times 100 \%
$$

where $M_{t, H M F}$ and $M_{t, D F F}$ are the quantities of moles at a moment $t$ of $H M F$ and DFF, respectively, and the $M_{O, H M F}$ is the initial amount of $H M F$.

\section{Results and Discussion}

Figure 2a shows the XRD pattern of the obtained $\mathrm{TiO}_{2}$. The main diffraction peaks of (101), (103), (004), (112), (200), (105), (211), (213), (204), (116), (220), and (215) correspond to the crystal planes of anatase phase. It is well known that anatase $\mathrm{TiO}_{2}$ exhibits more appropriate photocatalytic properties compared to rutile $\mathrm{TiO}_{2}$ [18]. Using Equation (1), the value of crystallite size of $\mathrm{TiO}_{2} \mathrm{NPs}$ was determined to be $17.4 \mathrm{~nm}$. The calculation was in good agreement with the TEM results.

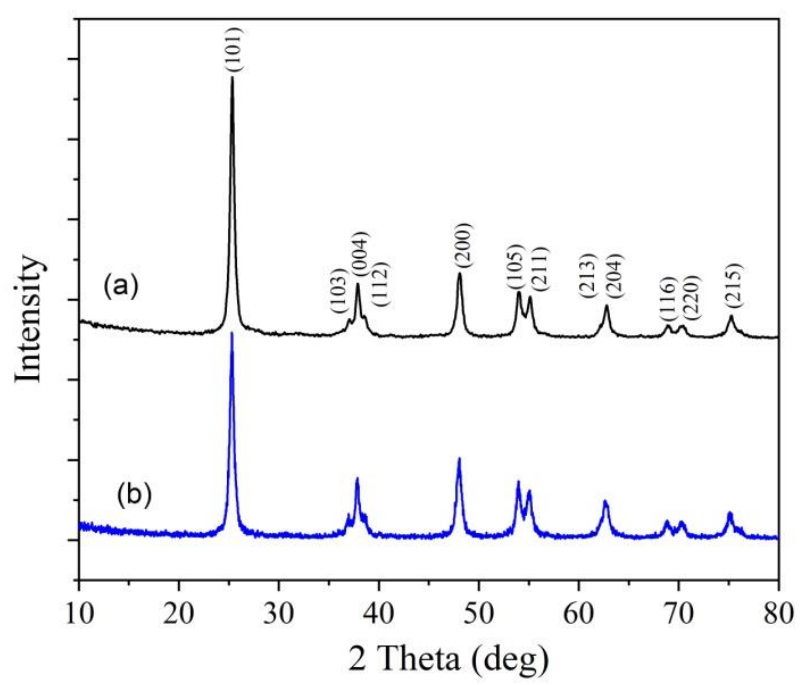

Figure 2. XRD patterns of $\mathrm{TiO}_{2}$ nanoparticles before (a) and after (b) photocatalysis.

The EDS spectrum (inset in Figure 3a) shows the presence of peaks associated with the elements $\mathrm{Ti}(0.4 \mathrm{keV}$ and $4.5 \mathrm{keV})$ and $\mathrm{O}(0.5 \mathrm{keV})$, confirming the characteristic components of $\mathrm{TiO}_{2}$. 
The HRTEM image (Figure 3b) shows individual nanocrystals with clear one-dimensional lattice fringes. The interplanar distance of $0.35 \mathrm{~nm}$ of the $\mathrm{TiO}_{2}$ NPs correspond to the (101) plane of anatase [19].
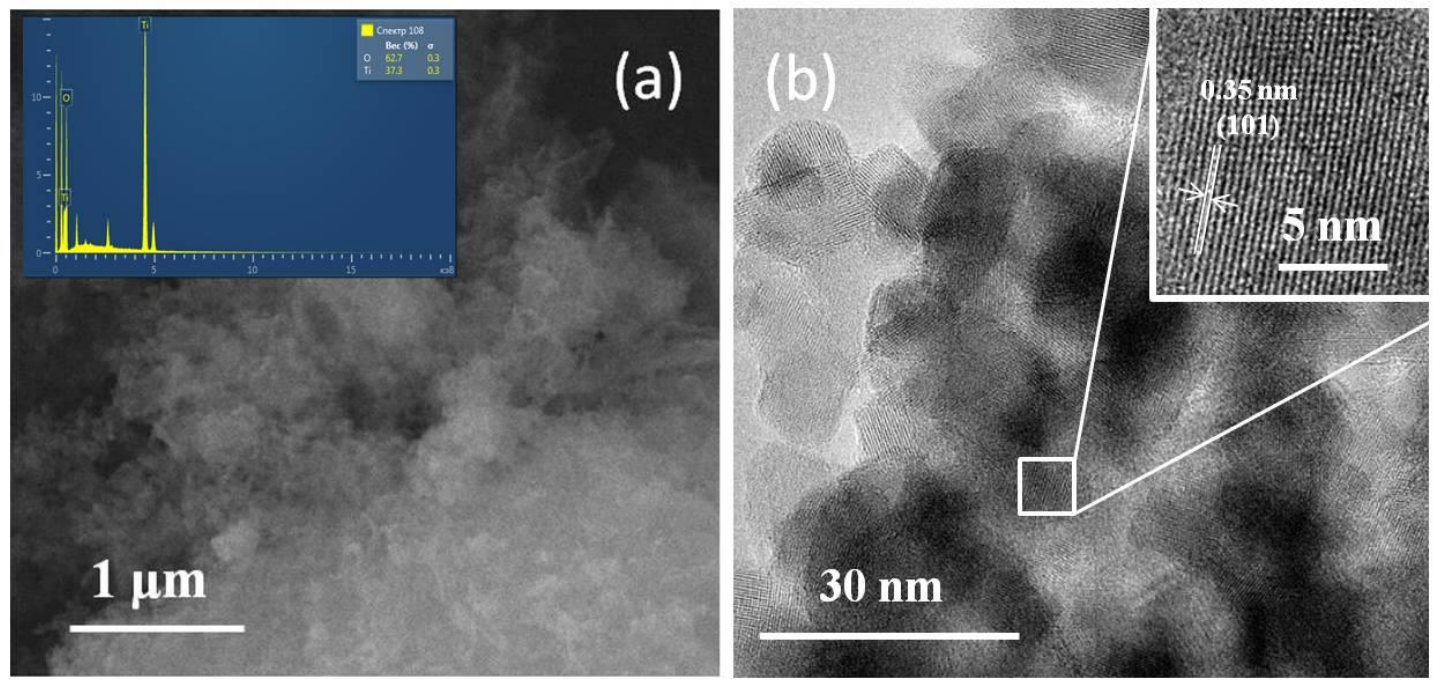

Figure 3. SEM (a) and HRTEM (b) images of $\mathrm{TiO}_{2}$ nanoparticles.

The specific surface area of $\mathrm{TiO}_{2}$ NPs synthesized by the electrochemical method using pulse alternating current was measured using BET analysis. Figure 4 displays the $\mathrm{N}_{2}$ adsorption-desorption isotherms of $\mathrm{TiO}_{2}$. The sample presents a type-IV isotherm with a $\mathrm{H} 3$ type hysteresis. The BET surface area was calculated to be $58.6 \mathrm{~m}^{2} \mathrm{~g}^{-1}$.

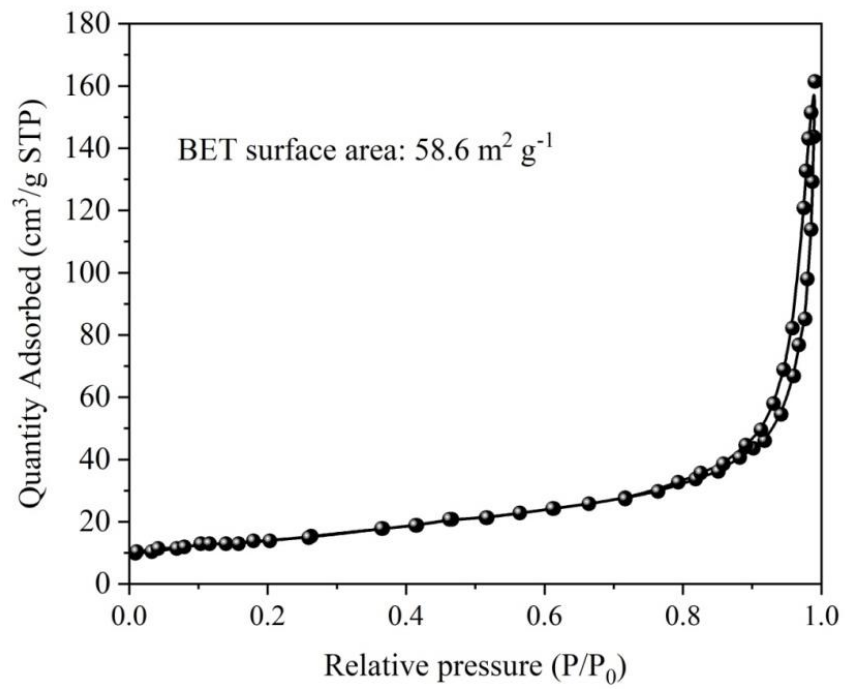

Figure 4. $\mathrm{N}_{2}$ adsorption-desorption isotherm of $\mathrm{TiO}_{2}$ nanoparticles.

The detected product of HMF photooxidation is mainly DFF, which is consistent with literature [20]. In the dark or when exposed to light in the absence of a catalyst, no DFF was obtained, suggesting that both light and catalyst are necessary for this photocatalytic oxidation reaction. The efficiency of the electrochemically synthesized $\mathrm{TiO}_{2} \mathrm{NPs}_{\text {in }}$ the HMF photooxidation reaction with and without scavengers was evaluated (Figure 5a). The corresponding DFF selectivity values were demonstrated in Figure 5b. As can be seen, HMF can be almost completely oxidized without adding any trapping species over $360 \mathrm{~min}$ at a light intensity of $3 \mathrm{~mW} \mathrm{~cm}{ }^{-2}$ with DFF selectivity of approximately $10 \%$. Moreover, HMF degradation during self-photolysis cannot be ignored. It should be considered, 
however, that the contribution of photolysis in the presence of photocatalyst is always less significant due to the shielding effect of the suspended powder.
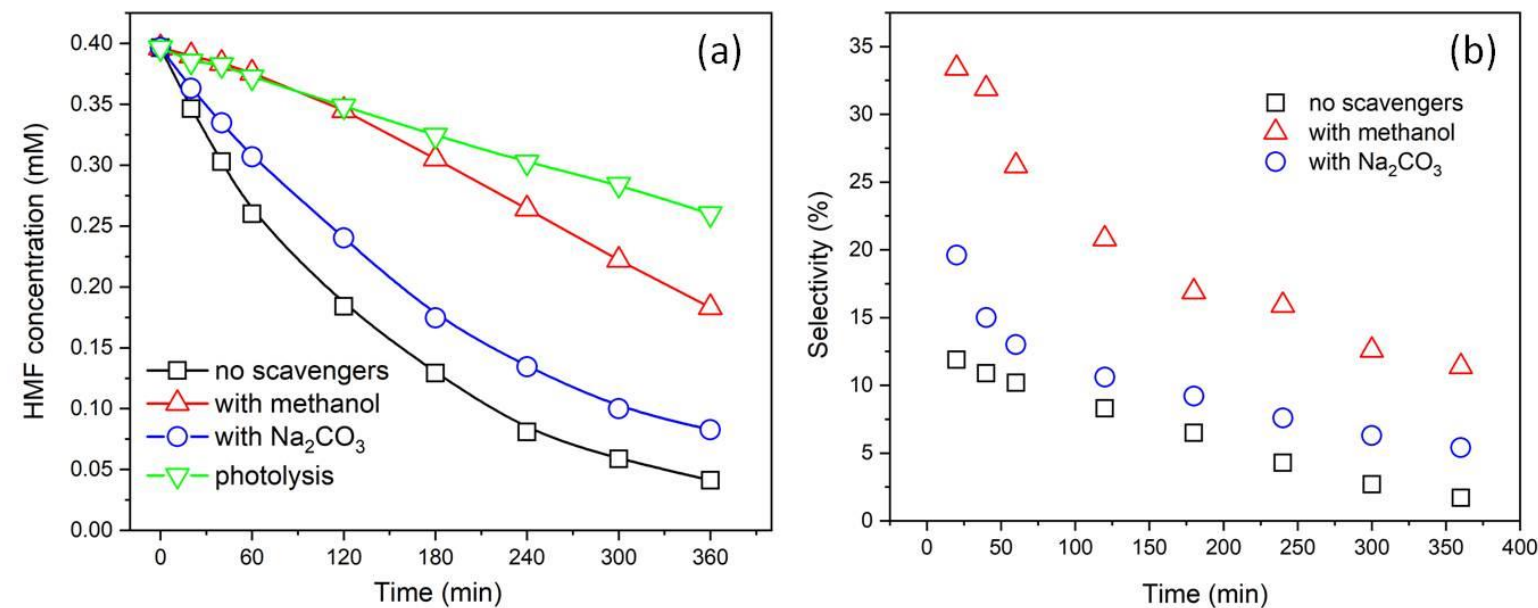

Figure 5. Effect of scavengers on 5-hydroxymethylfurfural (HMF) photocatalytic oxidation (a) and 2,5-diformylfuran (DFF) selectivity (b). Experimental conditions: light irradiation intensity $3.0 \mathrm{~mW} \mathrm{~cm}^{-2}$, catalyst dosage $1 \mathrm{~g} \mathrm{~L}^{-1}, \mathrm{HMF}$ concentration $0.4 \mathrm{mM}, \mathrm{O}_{2}$ flow $3 \mathrm{~mL} \mathrm{~min}^{-1}$.

In order to improve the selectivity for the partial oxidation reaction, methanol and $\mathrm{Na}_{2} \mathrm{CO}_{3}$ were added to the reaction suspension as a hole and an $\mathrm{OH} \bullet$ scavenger, respectively. It was observed that a strong decrease in HMF oxidation efficiency was accompanied by an increase in the selectivity of DFF compared to a similar run carried out in the absence of methanol. It is noteworthy that the $\mathrm{Na}_{2} \mathrm{CO}_{3}$ trapping agent had a slight effect on DFF selectivity during HMF oxidation. These results indicate that in a methanol-containing photocatalytic system, alcohol acts as an efficient hole trap by preventing the deep mineralization of HMF and increasing selectivity for the target DFF. In a previous paper [9], a similar trend was observed for poorly crystallized $\mathrm{TiO}_{2}$. The evolution of DFF slowed down with time (Figure $5 b$ ), which may be due to its overoxidation.

The effect of UVA light intensity on DFF selectivity was also examined. It was found that an increase in light intensity leads to an increase in overall efficiency of HMF degradation (Figure 6a), but decreases the selectivity of DFF (Figure 6b), probably due to higher contribution of direct photolysis processes at higher light intensities [11].
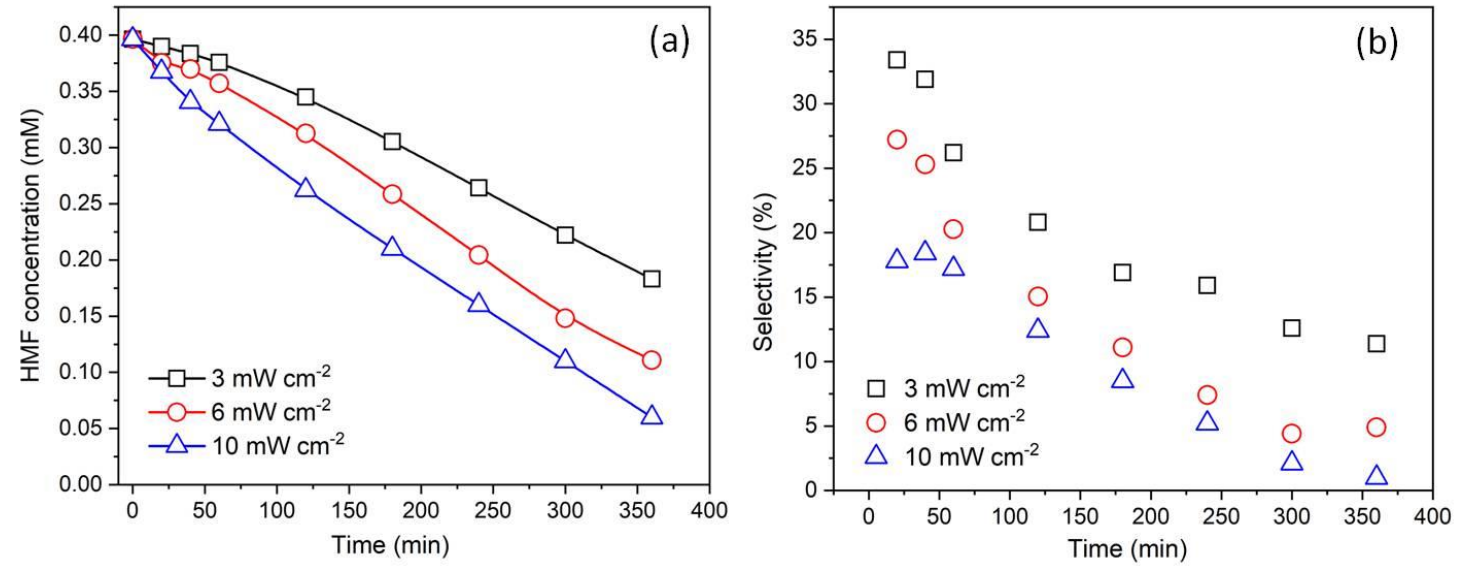

Figure 6. Experimental results on photocatalytic oxidation of HMF (a) and DFF selectivity (b) depending on irradiation intensity in the presence of electrochemically synthesized $\mathrm{TiO}_{2}$ and methanol. Experimental conditions: catalyst dosage $1 \mathrm{~g} \mathrm{~L}^{-1}$, HMF concentration $0.4 \mathrm{mM}$, methanol concentration $50 \mathrm{mM}, \mathrm{O}_{2}$ flow $3 \mathrm{~mL} \mathrm{~min}^{-1}$. 
The obtained selectivity toward DFF (up to $33 \%$ ) for electrochemically synthesized $\mathrm{TiO}_{2} \mathrm{NPs}$ was higher than for the previously reported titanium oxide samples prepared by microemulsion and sol-gel methods [9,12]. A run carried out for comparison with the commercial $\mathrm{TiO}_{2}$ Evonik P25 (not reported here) showed that the commercial catalyst was more active in the decomposition of HMF; however, in this case, DFF was formed only in trace amounts $(\sim 1 \%)$. This may be due to the higher level of crystallinity in the commercial sample [9]. A comparison between the photocatalytic performance of the electrochemically synthesized $\mathrm{TiO}_{2} \mathrm{NPs}$ and other $\mathrm{TiO}_{2}$ photocatalysts for $\mathrm{HMF}$ oxidation is presented in Table 1.

Table 1. Comparison of photocatalytic performance of the $\mathrm{TiO}_{2}$ nanoparticles (NPs) with other $\mathrm{TiO}_{2}$ photocatalysts for HMF oxidation.

\begin{tabular}{|c|c|c|c|c|c|}
\hline Sample & $\begin{array}{c}\text { HMF } \\
\text { Concentration }\end{array}$ & Irradiation Type & $\begin{array}{l}\text { HMF Conversion } \\
(\%)\end{array}$ & $\begin{array}{c}\text { DFF } \\
\text { Selectivity (\%) }\end{array}$ & Reference \\
\hline $\mathrm{TiO}_{2}-\mathrm{m}$ & $0.08 \mathrm{M}$ & $\begin{array}{l}300 \mathrm{~W} \text { Xe-lamp } \\
(250-2500 \mathrm{~nm})\end{array}$ & $\begin{array}{l}10 \\
12 \\
22\end{array}$ & $\begin{array}{l}2 \\
2 \\
5\end{array}$ & [12] \\
\hline $\mathrm{HPA}^{1}$ & $0.5 \mathrm{mM}$ & $\begin{array}{l}\text { four } 8 \text { W Philips lamps (365 nm) } \\
\qquad 3.0 \mathrm{~mW} \mathrm{~cm}^{-2}\end{array}$ & 20 & 26 & [9] \\
\hline $\mathrm{TiO}_{2} \mathrm{NPs}^{1}$ & $0.4 \mathrm{mM}$ & $\begin{array}{c}\text { Hamamatsu, LC8 }(365 \mathrm{~nm}) \\
3.0 \mathrm{~mW} \mathrm{~cm}^{-2}\end{array}$ & 15 & 29.5 & $\begin{array}{l}\text { the present } \\
\text { study }\end{array}$ \\
\hline comm- $-\mathrm{TiO}_{2}$ & $0.4 \mathrm{mM}$ & $\begin{array}{c}\text { Hamamatsu, LC8 }(365 \mathrm{~nm}) \\
3.0 \mathrm{~mW} \mathrm{~cm}^{-2}\end{array}$ & 60 & 1.0 & $\begin{array}{l}\text { the present } \\
\text { study }\end{array}$ \\
\hline
\end{tabular}

The reusability of the synthesized $\mathrm{TiO}_{2} \mathrm{NPs}$ has been verified by recycling experiments during which $\mathrm{TiO}_{2} \mathrm{NPs}$ was reused by centrifugation and washing with water. Recycling experiments suggest that HMF could be converted into DFF in three consecutive runs using recollected photocatalyst. It is worth mentioning that the selectivity values became even higher after the second run (Figure 7) than can be attributed to the decrease in $\mathrm{TiO}_{2}$ crystallinity.

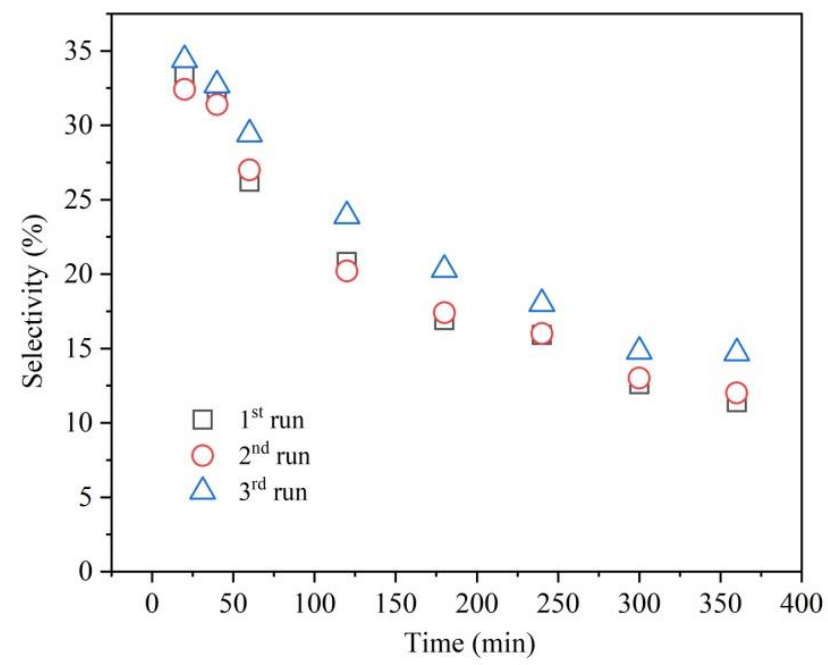

Figure 7. Cycling runs in photocatalytic oxidation of $\mathrm{HMF}$ over electrochemically synthesized $\mathrm{TiO}_{2}$.

The stability of the $\mathrm{TiO}_{2}$ photocatalyst after the HMF photocatalytic oxidation has also been investigated using XRD analysis, which is shown in Figure $2 \mathrm{~b}$. The results suggested that the crystallinity of the $\mathrm{TiO}_{2} \mathrm{NPs}$ becomes slightly lower after its third usage, which may be due to the photocorrosion of the catalyst. In addition, the higher background in the diffraction pattern of the $\mathrm{TiO}_{2}$ sample after photocatalysis is consistent with the appearance of some amorphous phase in the sample. However, no other diffraction peaks were observed after the third photocatalytic run. 


\section{Conclusions}

Photocatalytic oxidation of HMF in water can provide an environmentally benign method to produce valuable DFF. Electrochemical synthesis using pulse alternating current was carried out to prepare $\mathrm{TiO}_{2}$ nanoparticles with a higher selectivity toward DFF (up to 33\%) compared to the commercial $\mathrm{TiO}_{2}$ sample. Photocatalytic selective oxidation of $\mathrm{HMF}$ to form DFF using electrochemically synthesized $\mathrm{TiO}_{2}$ can be scaled up after optimization of all parameters.

Author Contributions: Investigation, A.U.; writing-original draft preparation, A.U.; writing-review and editing, S.M.; supervision, N.S. All authors have read and agreed to the published version of the manuscript.

Funding: This research was funded by RUSSIAN SCIENCE FOUNDATION, grant number 16-13-10444.

Acknowledgments: The authors thank the Shared Research Center "Nanotechnologies" of Platov South-Russian State Polytechnic University (NPI) for HPLC and XRD analyses.

Conflicts of Interest: The authors declare no conflict of interest.

\section{References}

1. Klushin, V.A.; Galkin, K.I.; Kashparova, V.P.; Krivodaeva, E.A.; Kravchenko, O.A.; Smirnova, N.V.; Chernyshev, V.M.; Ananikov, V.P. Technological aspects of fructose conversion to high-purity 5-hydroxymethylfurfural, a versatile platform chemical. Russ. J. Org. Chem. 2016, 52, 767-771. [CrossRef]

2. Ghosh, K.; Molla, R.A.; Iqubal, M.A.; Islam, S.S.; Islam, S.M. Ruthenium nanoparticles supported on $\mathrm{N}$-containing mesoporous polymer catalyzed aerobic oxidation of biomass-derived 5-hydroxymethylfurfural (HMF) to 2,5-diformylfuran (DFF). Appl. Catal. A Gen. 2016, 520, 44-52. [CrossRef]

3. Teng, N.; Li, J.-L.; Lu, B.-Q.; Wang, Y.-Q.; Jia, S.-Y.; Wang, Y.-X.; Hou, X.-L. The selective aerobic oxidation of 5-hydroxymethylfurfural to produce 2,5-diformylfuran using Nitrogen-doped porous carbons as catalysts. New Carbon Mater. 2019, 34, 593-599. [CrossRef]

4. Ding, L.; Yang, W.; Chen, L.; Cheng, H.; Qi, Z. Fabrication of spinel CoMn ${ }_{2} \mathrm{O}_{4}$ hollow spheres for highly selective aerobic oxidation of 5-hydroxymethylfurfural to 2,5-diformylfuran. Catal. Today 2018. [CrossRef]

5. Mamaghani, A.H.; Haghighat, F.; Lee, C.-S. Hydrothermal/solvothermal synthesis and treatment of $\mathrm{TiO}_{2}$ for photocatalytic degradation of air pollutants: Preparation, characterization, properties, and performance. Chemosphere 2019, 219, 804-825. [CrossRef] [PubMed]

6. Wang, R.; Ma, X.; Liu, T.; Li, Y.; Song, L.; Tjong, S.C.; Cao, L.; Wang, W.; Yu, Q.; Wang, Z. Degradation aspects of endocrine disrupting chemicals: A review on photocatalytic processes and photocatalysts. Appl. Catal. A Gen. 2020, 597, 117547. [CrossRef]

7. Akbari, A.; Amini, M.; Tarassoli, A.; Eftekhari-Sis, B.; Ghasemian, N.; Jabbari, E. Transition metal oxide nanoparticles as efficient catalysts in oxidation reactions. Nano Struct. Nano Objects 2018, 14, 19-48. [CrossRef]

8. Chen, L.; Tang, J.; Song, L.-N.; Chen, P.; He, J.; Au, C.-T.; Yin, S.-F. Heterogeneous photocatalysis for selective oxidation of alcohols and hydrocarbons. Appl. Catal. B Environ. 2019, 242, 379-388. [CrossRef]

9. Yurdakal, S.; Tek, B.S.; Alagöz, O.; Augugliaro, V.; Loddo, V.; Palmisano, G.; Palmisano, L. Photocatalytic Selective Oxidation of 5-(Hydroxymethyl)-2-furaldehyde to 2,5-Furandicarbaldehyde in Water by Using Anatase, Rutile, and Brookite $\mathrm{TiO}_{2}$ Nanoparticles. ACS Sustain. Chem. Eng. 2013, 1, 456-461. [CrossRef]

10. Wu, Q.; He, Y.; Zhang, H.; Feng, Z.; Wu, Y.; Wu, T. Photocatalytic selective oxidation of biomass-derived 5-hydroxymethylfurfural to 2,5-diformylfuran on metal-free g- $\mathrm{C}_{3} \mathrm{~N}_{4}$ under visible light irradiation. Mol. Catal. 2017, 436, 10-18. [CrossRef]

11. Zhang, H.; Feng, Z.; Zhu, Y.; Wu, Y.; Wu, T. Photocatalytic selective oxidation of biomass-derived 5-hydroxymethylfurfural to 2,5-diformylfuran on $\mathrm{WO}_{3} / \mathrm{g}-\mathrm{C}_{3} \mathrm{~N}_{4}$ composite under irradiation of visible light. J. Photochem. Photobiol. A Chem. 2019, 371, 1-9. [CrossRef]

12. Lolli, A.; Maslova, V.; Bonincontro, D.; Basile, F.; Ortelli, S.; Albonetti, S. Selective Oxidation of HMF via Catalytic and Photocatalytic Processes Using Metal-Supported Catalysts. Molecules 2018, 23, 2792. [CrossRef] [PubMed]

13. Lozano-Morales, S.A.; Morales, G.; López Zavala, M.Á.; Arce-Sarria, A.; Machuca-Martínez, F. Photocatalytic Treatment of Paracetamol Using $\mathrm{TiO}_{2}$ Nanotubes: Effect of pH. Processes 2019, 7, 319. [CrossRef] 
14. Ulyankina, A.A.; Kuriganova, A.B.; Smirnova, N.V. Photocatalytic properties of $\mathrm{SnO}_{2}-\mathrm{SnO}$ nanocomposite prepared via pulse alternating current synthesis. Mendeleev Commun. 2019, 29, 215-217. [CrossRef]

15. Ulyankina, A.; Leontyev, I.; Avramenko, M.; Zhigunov, D.; Smirnova, N. Large-scale synthesis of ZnO nanostructures by pulse electrochemical method and their photocatalytic properties. Mater. Sci. Semicond. Process. 2018, 76, 7-13. [CrossRef]

16. Chernysheva, D.; Vlaic, C.; Leontyev, I.; Pudova, L.; Ivanov, S.; Avramenko, M.; Allix, M.; Rakhmatullin, A.; Maslova, O.; Bund, A.; et al. Synthesis of $\mathrm{Co}_{3} \mathrm{O}_{4} / \mathrm{CoOOH}$ via electrochemical dispersion using a pulse alternating current method for lithium-ion batteries and supercapacitors. Solid State Sci. 2018, 86, 53-59. [CrossRef]

17. Ulyankina, A.; Leontyev, I.; Maslova, O.; Allix, M.; Rakhmatullin, A.; Nevzorova, N.; Valeev, R.; Yalovega, G.; Smirnova, N. Copper oxides for energy storage application: Novel pulse alternating current synthesis. Mater. Sci. Semicond. Process. 2018, 73, 111-116. [CrossRef]

18. Luttrell, T.; Halpegamage, S.; Tao, J.; Kramer, A.; Sutter, E.; Batzill, M. Why is anatase a better photocatalyst than rutile?-Model studies on epitaxial $\mathrm{TiO}_{2}$ films. Sci. Rep. 2014, 4, 4043. [CrossRef] [PubMed]

19. Sathiyan, K.; Bar-Ziv, R.; Mendelson, O.; Zidki, T. Controllable synthesis of $\mathrm{TiO}_{2}$ nanoparticles and their photocatalytic activity in dye degradation. Mater. Res. Bull. 2020, 126, 110842. [CrossRef]

20. Ma, B.; Wang, Y.; Guo, X.; Tong, X.; Liu, C.; Wang, Y.; Guo, X. Photocatalytic synthesis of 2,5-diformylfuran from 5-hydroxymethyfurfural or fructose over bimetallic $\mathrm{Au}-\mathrm{Ru}$ nanoparticles supported on reduced graphene oxides. Appl. Catal. A Gen. 2018, 552, 70-76. [CrossRef]

(C) 2020 by the authors. Licensee MDPI, Basel, Switzerland. This article is an open access article distributed under the terms and conditions of the Creative Commons Attribution (CC BY) license (http://creativecommons.org/licenses/by/4.0/). 